\title{
Mekanistik-Ampirik ve Geleneksel Beton Yol Tasarım Yöntemlerinin Karşılaştırılması: Afyon-Emirdağ Deneme Kesimi
}

\author{
Emin ŞENGÜN ${ }^{1}$ \\ Hande I. ÖZTÜRK ${ }^{2}$ \\ I. Özgür YAMAN ${ }^{3}$
}

ÖZ

Türkiye'nin Karayolları Genel Müdürlüğü bünyesindeki ilk beton yol uygulaması olan Afyon-Emirdağ kesimi derzli donatısız beton kaplama olarak Belçika Katalog yöntemine göre tasarlanmıştır. Bu tasarım, hem geleneksel Amerikan Devlet Karayolu ve Taşımacılık İdareleri Birliği ampirik tasarım yöntemi (AASHTO 93) hem de mekanistik-ampirik (M-E) üstyapı tasarım yöntemi ile yeniden analiz edilerek, mevcut yol üzerinden aralıklarla ölçülen düzgünsüzlük (IRI) değerleri ile karşılaştırılmıştır. Saha ölçümleri ile M-E analizleri sonucu tahmin edilen IRI değerlerinin birbirine oldukça yakın olduğu tespit edilmiştir. M-E analizleri sonucunda mevcut yolun servis sürecinde düzgünsüzlük ve faylanma performans kriterlerine göre sınır değerleri aşacağı, ancak enine çatlak yönünden sınır değerler içinde kalacă̆1 öngörülmüştür.

Anahtar Kelimeler: Üstyapı tasarımı, Belçika katalog yöntemi, AASHTO 93 tasarım yöntemi, mekanistik-ampirik (M-E) tasarımı.

\section{ABSTRACT \\ Comparison of Mechanistic-Empirical and Traditional Rigid Pavement Design Methods: Afyon-Emirdağ Trial Section}

The first rigid pavement section in Turkey under the jurisdiction of General Directorate of Highways was designed as Jointed plain concrete pavement (JPCP) according to Belgian Catalog method. This design was compared with the traditional empirical American

\footnotetext{
Not: Bu yazı

- Yayın Kurulu'na 15 Mayıs 2019 günü ulaşmıştır. 4 Aralık 2019 günü yayımlanmak üzere kabul edilmiştir.

- 30 Kasım 2020 gününe kadar tartışmaya açıktır.

- https://dx.doi.org/10.18400/tekderg.565709

1 Ankara Yıldırım Beyazıt Üniversitesi, İnşaat Mühendisliği Bölümü, Ankara - esengun@ybu.edu.tr https://orcid.org/0000-0001-7082-0061

2 Orta Doğu Teknik Üniversitesi, İnşaat Mühendisliği Bölümü, Ankara - ozturkha@metu.edu.tr https://orcid.org/0000-0003-1597-5348

3 Orta Doğu Teknik Üniversitesi, İnşaat Mühendisliği Bölümü, Ankara - ioyaman@metu.edu.tr https://orcid.org/0000-0001-6489-6852
} 
Association of State Highway and Transportation Officials (AASHTO-93) design method and with the mechanistic-empirical (M-E) pavement design guide. Moreover, the international roughness index (IRI) values measured with intervals were compared with the predicted values of M-E analysis. According to M-E analysis, it is predicted that IRI and faulting will exceed but the cracking will be within the limit values during its service life.

Keywords: Concrete pavement design, Belgian Catalog method, AASHTO 93 design method, mechanistic-empirical (M-E) design.

\section{GíRiş}

Türkiye'nin şehirlerarası yollardaki ilk beton yol uygulaması, Karayolları Genel Müdürlüğü (KGM) ile Türkiye Çimento Müstahsilleri Birliği (TÇMB) arasında imzalanan bir protokol çerçevesinde, Afyon-Emirdağ Ayrımı (İşcehisar Geçişi) Km: 5+700-7+700 arasında 2 km'lik bölünmüş tek yönlü 3 şeritli taşıt yolunda TÇMB tarafından finanse edilerek gerçekleştirilmiş ve Haziran 2004 tarihinde trafiğe açılmıştır [1]. Daha önceden ülkemiz genelinde projelendirilmiş bir beton yol uygulaması olmadığından, beton yol tasarımı aşamasında ilgili teknik şartnamenin hazırlanması için Belçika Çimento Birliği (FEBELCEM) uzmanlarından yararlanılmıştır. Beton yol uygulaması üzerine önemli bir bilgi birikimine ve tecrübeye sahip olan Belçika Yol Araştırma Merkezi tarafından hazırlanan Belçika Katalog yöntemi (Centre de Recherches Routieres-CRR) deneme kesiminin tasarımında kullanılmıştır [2,3]. Belçika Yol Araştırma Merkezinde 30 seneyi geçen araştırma ve gözlemlere bağlı olarak üstyapıda meydana gelen çatlak ve deformasyonlar, trafik yükü, zemin özellikleri, iklim koşulları ve malzeme özellikleri de dikkate alınarak geliştirilen katalog yöntemi, tasarımcılara hızlı ve kolay bir şekilde tasarım yapılabilmesine olanak sağlamaktadır [4]. Hem katalog hem de analitik yöntemde tasarımı, beton kaplama tipi (sürekli donatılı veya derzli donatısız), hizmet ömrü, beklenen trafik, taban zemin özellikleri ve üstyapı malzeme özellikleri ile sıcaklık vb. iklim koşullarına bağlı parametreler etkilemektedir [4]. Dünya genelinde, üstyapı tasarım yöntemi olarak ampirik AASHTO 93 Rijit Üstyapı Yöntemi (Amerika Devlet Karayolları ve Ulaştırma İdareleri Birliği) oldukça sık kullanılmasına rağmen, bu beton yol uygulaması için Belçika Katalog yönteminin seçilmesinin en önemli nedenlerinden birisi yöntemin oldukça basit ve pratik olmasıdır.

Ancak gelişen teknolojik birikim ile başta $\mathrm{ABD}$ olmak üzere yol üstyapı tasarımı üzerine önemli çalışmalar yapılarak daha gerçekçi ve sürdürülebilir tasarımların ortaya çıkması adına ampirik tasarım yönteminden (AASHTO 93), mekanistik tasarım yöntemine doğru geçişte önemli adımlar atılmaktadır. ABD'de NCHRP (Ulusal Karayolları Birliği Araştırma Programı) tarafından 2002 yılında geliştirilen MEPDG (Mekanistik-Ampirik Üstyapı Tasarım Rehberi) bu amaca yönelik ilk tasarım yöntemidir ve yıllar içinde geliştirilerek günümüzde kullanılan halini almıştır [5,6]. Sonlu elemanlar yöntemine dayanarak geliştirilen bir yazılım sayesinde (AASHTOWare 2.0) bu yeni nesil mekanistik-ampirik (M-E) tasarım yönteminin mekanik kısmını, maruz kalınan trafik yüklerine ve çevresel koşullara bağlı olarak üstyapıda meydana gelecek gerilme, gerinim ve deformasyonların hesapları oluşturmaktadır. Diğer taraftan bu mekanistik büyüklüklerin, güvenilirlik katsayısı da göz önüne alınarak ampirik bozulma transfer fonksiyonlarına (distress transfer function) bağlı olarak çatlak, faylanma ve düzgünsüzlük gibi üstyapı performansını etkileyen parametrelere dönüştürülmesi ve zamana göre tahmin edilebilmesi de tasarımın ampirik kısmını 
oluşturmaktadır [7]. Bundan dolayı tasarımın ampirik kısmını oluşturan üstyapıda meydana gelecek bozulmaların tahmin edilebilmesi için mevcut daha önceki üstyapı tecrübe ve gözlemlerine de dayanarak programın yerel kalibrasyonun yapılması, tasarımın daha gerçekçi sonuç vermesi ve bozulma tahminlerinin daha doğru yapabilmesi adına oldukça önemlidir. M-E tasarımın daha gerçekçi sonuçlar verebilmesi adına gerçekleştirilen yerel kalibrasyon çalışmaları, tasarımın ilk olarak geliştirildiği ve 2004 yılından itibaren eyaletler bazında kullanımına başlanan ABD'de halen devam etmekte olup, saha ölçümleri ile tasarım çıktıları karşılaştırılmakta ve elde edilen bulgular uluslararası literatürde sunulmaktadır [813]. Ayrıca tasarımın ortaya çıtı̆̆ı ABD ve Kanada haricinde, Arjantin [14], Katar [15], Peru [16], Mısır [17], İran [18], Hindistan [19], Çin [20], Şili [21], Lübnan [22], Suudi Arabistan [23], Kore [24] ve İtalya [25] gibi diğer ülkelerde de M-E üstyapı tasarıma yönelik çalışmalara başlanılmış olup, yerel kalibrasyonuna yönelik çalışmalar devam etmektedir. Ülkemizde ise M-E tasarımına geçiş için yapılan ilk çalışma Öztürk vd. 2018 [7] tarafından farklı trafik, zemin, malzeme ve iklim koşulları için M-E yöntemle tasarlanan derzli donatısız rijit üstyap1 sistemlerinin karşılaştırılması üzerinedir. Ancak bu çalışma kapsamında kullanılan tasarım girdileri, MEPDG'de önerilen ortalama değerlerdir.

Bu çalışma ile KGM bünyesindeki ilk beton yol uygulaması olan Afyon-Emirdağ Ayrımı İsçehisar Geçişi deneme kesiminin, yaygın olarak tercih edilen geleneksel ampirik üstyapı tasarım yöntemine (AASHTO 93) göre tekrar tasarlanarak kaplama kalınlığının belirlenmesi ve yeni nesil mekanistik-ampirik tasarım yöntemine (M-E) göre seçilen hizmet ömrü boyunca mevcut üstyapının performans analizlerinin yapılması amaçlanmıştır. $\mathrm{Bu}$ çalışmanın materyal kısmını mevcut beton yol kaplama tasarım bilgileri ve performans ölçüm değerleri oluşturmaktadır. Çalışmada mevcut üstyapının farklı güvenilirlik ve trafik artış yüzdelerinde tekrar tasarlanması için AASHTO 93 yöntemi ile mevcut üstyapının yıllara göre değişen performans analizlerinin yapılabilmesi için M-E tasarım metodu kullanılmıştır. Çalışmanın değerlendirme bölümünde ise hem farklı güvenilirlik ve trafik artış yüzdelerine göre tekrar tasarlanan yolun kaplama kalınlığı ile mevcut yol tasarım kalınlığ 1 karşılıklı irdelenmiş, hem de M-E tasarım yönteminin ülkemizde uygulanabilirliği için gerekli olan yerel kalibrasyon çalışmalarına öncülük etmesi için ilgili deneme kesimine ait KGM tarafından ölçülen beton yol kaplaması düzgünsüzlük değerleri ile M-E kullanılarak hesaplanan IRI (Uluslararası Düzgünsüzlük İndeksi) değerlerinin karşılaştırılması yapılmıştır. Çalışmanın son bölümünde ise elde edilen bulgular kısaca özetlenerek ileriye dönük beton yol tasarım çalışmaları ve yerinde uygulamalar için tavsiyelerde bulunulmuştur. $\mathrm{Bu}$ çalışma ile ülkemizde M-E tasarım yönteminin işlevselliği, gerçekçiliği ve lokal kalibrasyonu adına önemli bir adım atılmış olacaktır.

\section{MEVCUT BETON YOL KAPLAMA TASARIM BILLGILERI VE PERFORMANS ÖLÇÜM DEĞERLERI}

Türkiye'nin KGM bünyesindeki ilk beton yol uygulaması olan Afyon-Emirdağ deneme kesiminin tipik en kesiti Şekil 1'de gösterilmiştir. Yeğinobalı'nın [2] raporunda yolun belirli bölümlerinde yaklaşık $1,5 \mathrm{~cm}$ kalınlığında sathi asfalt kaplamanın bulunduğu ve kot farklılıkları nedeniyle beton kaplama kalınlığının deneme kesiminde 27-30 cm arasında değiştiği belirtilmiştir [1,2]. 
Ülkemizde KGM'ye ait esnek üstyapı tasarım rehberi bulunmasına rağmen rijit üstyapı tasarım rehberi bulunmadığından, beton yol tasarımı ve ilgili teknik şartnamelerinin hazırlanması için Belçika Çimento Birliği (FEBELCEM) uzmanlarından yararlanılmış ve tasarımda Belçika Katalog yöntemi kullanılmıştır [2]. Belçika Katalog yöntemine göre tabaka kalınlığını belirlenirken, trafik yükü, zemin temel, alt temel özellikleri, çevresel etkiler ve üstyapı malzeme özellikleri birlikte düşünülerek Belçika Şartnamesindeki B2 ( $<65$ milyon $100 \mathrm{kN}$ standart eşdeğer dingil yükü tekerrür sayısı, ESAL) sınıfına uygun olarak derzli donatısız üstyapı kaplama (DDBK) tipi önerilmiştir. İlk olarak B2 katalog sınıfına [26] göre temel üzerine $5 \mathrm{~cm}$ 'lik asfalt tabakası ve üzerine $23 \mathrm{~cm}$ 'lik beton plaka düşünülürken, daha sonra asfalt tabakadan vazgeçilerek $27 \mathrm{~cm}$ beton plaka kalınlığına geçilmiştir [2]. Bu deneme kesimi KGM bünyesindeki ilk beton yol uygulaması olduğundan, gelecek uygulamalara yön göstermesi için özellikle kaplamada meydana gelen bozulmalar ve performans değerleri zaman zaman kayıt altına alınmaktadır. Türkiye'de KGM bünyesinde toplam dört yerde deneme amaçlı beton yol uygulamasının yanı sıra, Türkiye genelinde il ve ilçe belediyeleri ya da il özel idareleri tarafından gerçekleştirilen şehir içi ya da köy bağlantı yollarında yapılan küçük ölçekli birçok uygulama mevcut olması rağmen bunlara ilişkin detaylı bilgiler bulunmadığı için değerlendirilmeye alınması mümkün olamamaktadır.

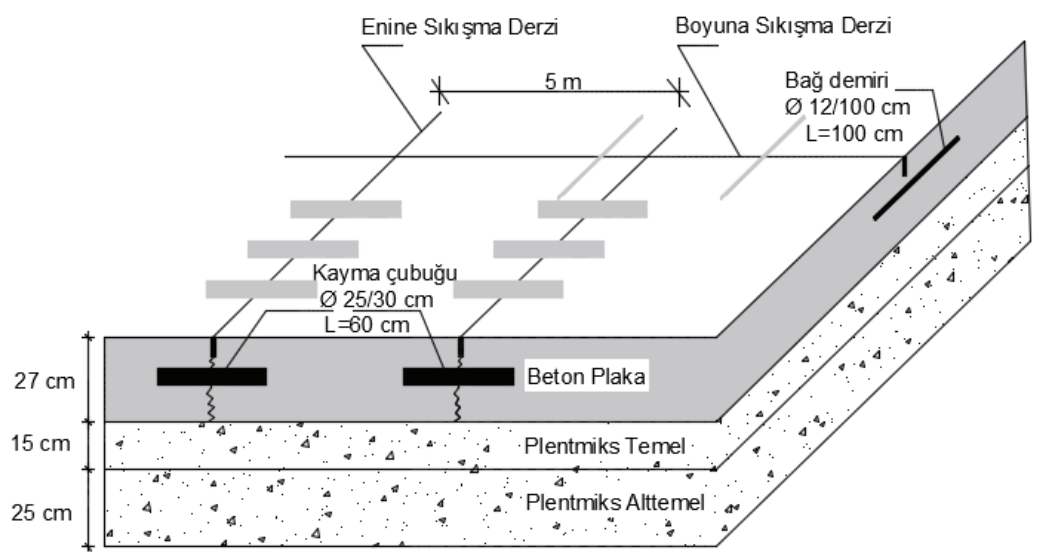

a) Beton yol üstyapı özellikleri

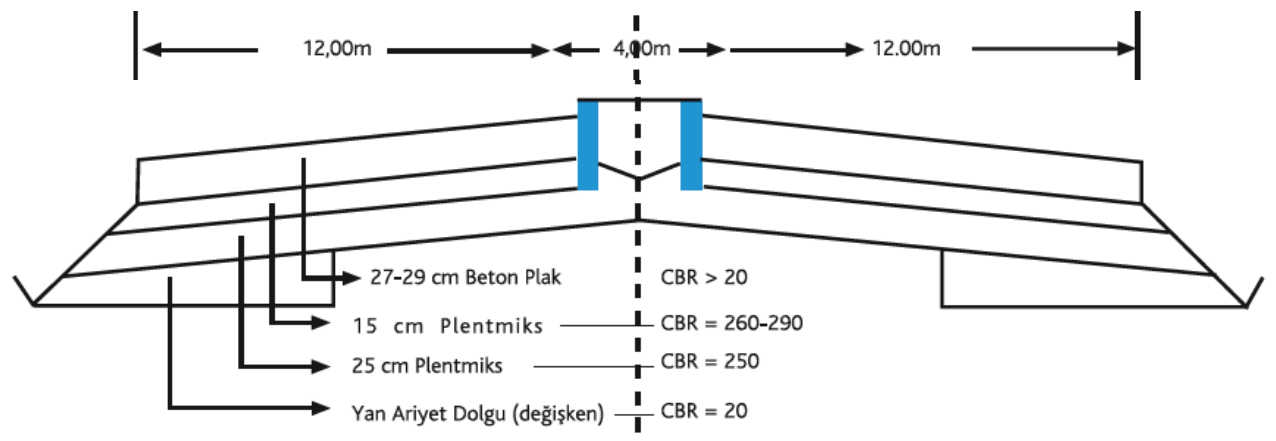

b) Beton yol tipik en kesiti

Şekil 1 - Afyon Emirdăg Ayrım Yolu beton üstyapı tipik en kesitleri [1,2]. 
Bu çalışma kapsamında incelenen bu yol kesimine ilişkin genel özellikler ile yol tasarımına ilişkin veriler Tablo 1'de derlenmiştir $[1,2]$.

Tablo.1 - Afyon-Emirdağ deneme kesimi beton yol tasarım verileri [1,2].

\begin{tabular}{ll}
\hline & \multicolumn{1}{c}{ Genel Bilgiler } \\
\hline Bölgesi & KGM 3.Bölge \\
Kilometresi & $5+700-7+700$ \\
Yapıldığı Tarih & Haziran 2004 \\
Yol Tipi & Derzli Donatısız Beton Kaplama (DDBK) \\
Beton Yol Uzunluğu & $2 \mathrm{~km}$ \\
Plaka Kalınlığı & $27 \mathrm{~cm}$ \\
Platform Genişliği & $12 \mathrm{~m}$ \\
Şerit Sayısı & 3 \\
Tasarım Yöntemi & Belçika Katalog Yöntemi \\
\hline & \multicolumn{2}{c}{ Trafik Verileri } \\
\hline
\end{tabular}

112 tir

2003 Y 1lı Ortalama Günlük 1323 kamyon

Taşıt (YOGT) Sayısı 550 otobüs

2061 otomobil

Beton Plağın Oturduğu Zemin Özellikleri

\begin{tabular}{ll}
\hline Plentmiks Temel & $\begin{array}{l}15 \mathrm{~cm} \\
\text { Plentmiks alt temel }\end{array}$ \\
\hline & \multicolumn{1}{c}{$25 \mathrm{~cm}$} \\
\hline Derz Aralığı & $5 \mathrm{~m}$ \\
Kayma Demiri Çapı & $25 \mathrm{~mm}$ \\
Kayma Demiri Boyu & $60 \mathrm{~cm}$ \\
Kayma Demiri Aralığı & $30 \mathrm{~cm}$ \\
\hline & \\
\hline Beton Dayanım Sınıfı & $\mathrm{C} 30 / 37$ \\
Su/Çimento & $0,41-0,47$ \\
CEM I 42.5 R & $375 \mathrm{~kg} / \mathrm{m}^{3}$ \\
Silis Dumanı & $17,5 \mathrm{~kg} / \mathrm{m}^{3}$ \\
Agrega & Kalker kökenli kırma çakıl ve kırma kum ile doğal kum karışımı, \\
\hline
\end{tabular}


Mevcut yolun yapımından itibaren yol yüzeyinde belli zaman aralıklarında KGM tarafından ölçümleri gerçekleştirilen yüzey düzgünsüzlügü, kayma direnci, kum yama yöntemi ile yap1 derinliği ölçüm değerleri ise Tablo 2'de verilmiştir.

Tablo.2 - Afyon-Emirdă̆ Ayrım yolu performans değerleri [1].

\begin{tabular}{cccc}
\hline Ölçüm Tarihi & IRI (m/km) & Kayma Direnci (SN) & Yapı Derinliği (mm) \\
\hline 2005 & 1,67 & - & 0,36 \\
2006 & 1,73 & 43 & 0,31 \\
2007 & 1,79 & - & - \\
2008 & 1,82 & 35 & 0,26 \\
2009 & 1,90 & 23 & - \\
2012 & 1,98 & - & - \\
\hline
\end{tabular}

Yüzey düzgünsüzlüğü, tamamlanan üstyapı kaplamasına ait kalite kontrolünün sağlanması veya mevcut üstyapının değerlendirilerek bakım ya da yeniden yapımına karar verilebilmesi amacıyla göz önüne alınan parametrelerin başında gelmektedir. Üstyapılar için yüzey düzgünsüzlüğünün belirlemesinde çoğunlukla Uluslararası Düzgünsüzlük İndeksi (IRI) kullanılmaktadır [27,28]. IRI, araç üzerine monte edilmiş kızılötesi alıcılara ve ivme ölçerlere sahip $80 \mathrm{~km} / \mathrm{saat}$ sabit hızla giden bir ölçüm aracı vasıtasıyla düşey doğrultuda elde edilen yolun boyuna profilinin bir ölçüt değeri olup, birimi m/km'dir [29]. KGM tarafindan da üstyapı yüzey düzgünsüzlük değerlendirmeleri için IRI değerleri ASTM E-950 [30] standardı referans alınarak kullanılmakta ve profilometreler ile ölçülmektedir. Mükemmel düzgünlükte bir yolda IRI değeri 0'a yaklaşırken, boyuna düzgünsüzlüğün artması ile IRI değeri de büyümektedir ve teorik olarak bir üst sınırı bulunmamaktadır. Limit IRI değerleri yol kaplama tipi, yolun fonksiyonu, limit hız değeri, yıllık ortalama günlük trafik (YOGT) değeri gibi parametrelere bağlı olarak ülkelere göre değişiklik göstermektedir [28]. Amerikan Ulusal Karayolları İdaresi (FHWA) tarafından yapılan bir çalışmada yeni yapılan bir beton yoldan beklenen ortalama IRI alt ve üst değerleri 0,89 ile $1,13 \mathrm{~m} / \mathrm{km}$ olarak belirtilmiştir [31]. Amerikan Beton Yollar Birliği (ACPA) ise $2,80 \mathrm{~m} / \mathrm{km}$ IRI değerini yola yeni bir yüzey kaplamasının gerekliliği için üst sınır olarak kabul etmektedir [32]. Türkiye'de ise KGM tarafından 2016 yılında yayınlanan Beton Yol Kaplamaları Teknik Şartnamesine göre tamamlanan beton yol kaplamalar için IRI değerinin en fazla 1,60 (m/ km) değerinde olmas1 istenmektedir [33].

Mevcut üstyapının değerlendirilmesi için kullanılan diğer önemli bir parametre de kayma direncidir. Üstyapıya ait kayma direnci standart ölçümler sonucu elde edilen kayma sayısı (Skid Number, SN) ile değerlendirilmekte ve 0 ile 100 aralığında değişmektedir. Kayma sayısı ne kadar büyükse yol yüzeyinin kaymaya karşı direncinin o kadar iyi olduğu anlaşılmaktadır. KGM tarafından sürtünme direnci ölçüm cihazı ile ASTM E-274 [34] şartnamesi referans alınarak $64 \mathrm{~km} / \mathrm{saat}( \pm 1,5)$ hız için yol yüzeyi kayma direnci belirlenmektedir. Beton Yol Kaplamaları Teknik Şartnamesine göre yoldan beklenen SN limit değerleri YOGT değerlerine göre değişiklik göstermektedir. YOGT değerinin 7000'den 
düşük olduğu hafif trafik hacimli yollarda SN değeri 35 ve üstü olarak istenirken, YOGT değerinin 7000 ve üzeri olduğu yüksek trafik hacimli yollarda bu değer 45 ve üzeri olarak istenmektedir [33]. Kayma direncini etkileyen en önemli parametrelerin başında mikro ve makro yol yüzeyi dokusu gelmektedir. Direkt olarak yol yüzeyi mikro dokusunun belirlenmesi oldukça zor olduğu için çoğunlukla dolaylı ölçüm teknikleri uygulanmaktadır. Diğer taraftan yol yüzeyi makro doku ölçümleri nispeten daha kolay olmakta genel olarak kum yama, lazer ve üç boyutlu fotoğraflama yöntemleri kullanılmaktadır $[35,36]$.

Kum yama yöntemi, yol yüzey makro doku derinliğinin belirlenmesi için tüm dünyada oldukça sık başvurulan yöntemlerden birisidir. İngiltere'de geliştirilen bu yöntemin temelini, hacmi bilinen bir malzemenin yol yüzeyine uygulanarak kapladığg toplam alanın ölçülmesi sonucu yol yüzeyinin ortalama derinliğinin bulunması oluşturmaktadır [37]. Bu amaçla standart boyutlarda ve hacmi bilinen bir miktar kum $(50 \mathrm{ml})$ kaplama girintilerini dolduracak şekilde yüzeye dairesel olarak yayılmakta ve ardından dairenin ortalama çapı ile kumun hacmi kullanılarak kum yüksekliği belirlenmektedir [38]. Beton Yol Kaplamaları Teknik Şartnamesine göre ortalama doku derinliği yollar için $0,6 \mathrm{~mm}$ ile 1,1 $\mathrm{mm}$ arasında olması beklenmektedir [33].

Tablo 2'deki mevcut yola ait IRI, SN ve yol yüzeyi yap1 derinliği 2016 yılında KGM tarafından yayınlanan Beton Yol Kaplamaları Teknik Şartnamesindeki sınır değerler ile karşılaştırıldığında, IRI ve yol yüzeyi yapı derinliğinin tüm yıllar için sınır aralıkları dışında kaldığı, SN değeri içinse 2008 yılından itibaren sınır değerin altına düştüğü görülmektedir. Ancak buradaki mevzu bahis yolun Türkiye'nin KGM bünyesindeki şehirlerarası yollardaki ilk beton yol deneme kesimi olduğu unutulmamalıdır. Örneğin düşük IRI değerleri ancak yol inşaatı sırasında gereken özeninin gösterilmesi ile belli tecrübeler 1şı̆̆ında sağlanabilmektedir.

\section{BETON YOL TRAFIK VERILERİ}

Rijit üstyapılar tasarımı için ABD'nin bazı yol idareleri ve birçok ülke idareleri tarafından halen AASHTO 93 yöntemi kullanılmaktadır. Öte yandan ABD'deki bazı eyalet yol idareleri ise M-E tasarım yöntemini tercih etmektedir [39]. Bu iki yöntem arasında daha önce değinilen farklılıklardan bir tanesi de trafik verilerinin kullanılması aşamasındadır. Her iki tasarım yönteminde de gerekli olan proje trafiğinin hesaplanabilmesi için KGM tarafından 2004-2017 yılları arasındaki Afyon-Emirdağ Ayrım yolu için verilen YOGT değeri elde edilmiştir (Tablo 3) [40].

ABD Ulusal Karayolları İdaresi (FHWA) [41] tarafından belirlenen taşıt grubu sınıflarına göre; AASHTO 93 rijit üstyapı tasarımı yöntemi için sınıf 2 ve üzeri olan otomobil, orta yüklü ticari taşıt, otobüs, kamyon ve treyler tipi taşıtların tamamı proje trafiği hesaplamasında dikkate alınırken, M-E tasarım yönteminde ise sadece sınıf 4 ve üzeri olan otobüs, kamyon ve treyler tipi ağır taşıtlar proje trafiğinde dikkate alınmaktadır [5],[41,42]. Bu nedenle Tablo 2'de verilen 2004-2017 yılları arasındaki Afyon Emirdağ Ayrım yolu YOGT değerleri, trafik artış yüzdeleri sınıf 2 ve üzeri, sınıf 4 ve üzeri ve ayrıca yoldaki kamyon ve treyler trafiği artışının saptanabilmesi için sınıf 6 ve üzeri olmak üzere üç ayrı şekilde incelenmiştir (Şekil 2). Şekil 2'den de görüldüğü üzere sınıf 2 ve üzeri için yaklaşık $\% 8$, sınıf 4 ve üzeri için yaklaşık \%3, sınıf 6 ve üzeri içinse yaklaşık \% $\%$ 'lik bir trafik artışı gerçekleşmiştir. Ayrıca artış oranlarından bu 13 yıllık süre içerisinde kamyon trafiğinin otobüs trafiğinden daha hızlı artış gösterdiği görülmektedir. 
Mekanistik-Ampirik ve Geleneksel Beton Yol Tasarım Yöntemlerinin ...

Tablo 3 - 2004-2017 yıları arasındaki Afyon-Emirdă̆ Ayrım yoluna ait YOGT değerleri [40].

\begin{tabular}{cccccc}
\hline \multicolumn{5}{c}{ Trafik Grubuna Ait YOGT Değerleri } \\
Y11 & Otomobil & $\begin{array}{c}\text { Orta yüklü } \\
\text { ticari taşı }\end{array}$ & Otobüs & Kamyon & Treyler \\
\hline $\mathbf{2 0 0 4}$ & 3686 & 385 & 409 & 1270 & 262 \\
$\mathbf{2 0 0 5}$ & 4126 & 436 & 427 & 1209 & 235 \\
$\mathbf{2 0 0 6}$ & 4212 & 526 & 461 & 1391 & 335 \\
$\mathbf{2 0 0 7}$ & 5488 & 551 & 404 & 1371 & 342 \\
$\mathbf{2 0 0 8}$ & 5433 & 628 & 392 & 1467 & 284 \\
$\mathbf{2 0 0 9}$ & 6049 & 608 & 434 & 1234 & 447 \\
$\mathbf{2 0 1 0}$ & 6491 & 704 & 429 & 1389 & 565 \\
$\mathbf{2 0 1 1}$ & 7407 & 691 & 425 & 1359 & 766 \\
$\mathbf{2 0 1 2}$ & 7546 & 646 & 420 & 1250 & 892 \\
$\mathbf{2 0 1 3}$ & 7620 & 732 & 480 & 1176 & 836 \\
$\mathbf{2 0 1 4}$ & 9142 & 406 & 381 & 1024 & 1117 \\
$\mathbf{2 0 1 5}$ & 11761 & 723 & 275 & 1004 & 1534 \\
$\mathbf{2 0 1 6}$ & 11069 & 496 & 318 & 1086 & 1347 \\
$\mathbf{2 0 1 7}$ & 11761 & 723 & 275 & 1004 & 1534 \\
\hline
\end{tabular}

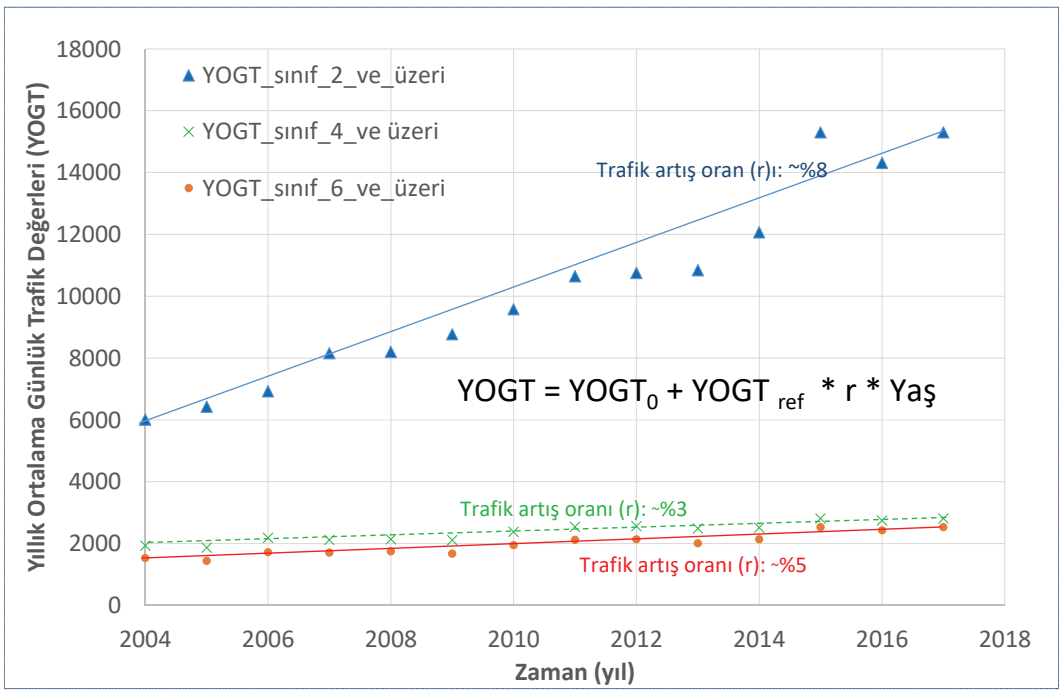

Şekil 2 - Afyon-Emirdă̆ Ayrım yoluna ait 2004-2017 yılları arasında trafik artış oranları [42]. 
Bu çalışmada, AASHTO 93 rijit üstyapı tasarım yönteminde üç farklı trafik artış yüzdesi (\%3, \%5 ve \%8) kullanılmıştır. Fakat M-E tasarım yöntem için kullanılan AASHTOWare 2.0 sonlu elemanlar programında sadece sınıf 4 ve üzeri taşıt grupları için veri girişine izin vermesinden dolayı M-E tasarımı için sadece $\% 3$ ve \%5'lik ağır taşıt trafiğindeki artış yüzdeleri kullanılmıştır. Sınıf 4 ve üzeri trafik artış oranının $\% 8$ olması çok anlamlı olmadığından M-E tasarımında bu trafik artış oranı kullanılmamıştır.

\section{AMPIRİK AASHTO 93 ÜSTYAPI TASARIMI}

Tasarım sırasında trafik verileri, alt temel ve temel kalınlıkları ve CBR (Kaliforniya Taşıma Oranı) değerleri ve ayrıca üstyapı malzeme özellikleri için mevcut deneme kesimine ait 2003 yılındaki tasarım verileri kullanılarak AASHTO 93 Rijit Üstyapı Tasarım Rehberine göre tasarım kalınlığı denklem (1) ile belirlenmiştir [43].

$$
\begin{aligned}
& \log \left(T_{8,2}\right)=Z_{R} \times S_{o}+7,35 \times \log (D+1)-0,06+\frac{\log \left(\frac{\Delta P S I}{4,2-1,5}\right)}{1+\frac{1,624 x 10^{7}}{(D+1)^{8,46}}}+\left(4,22-0,32 P_{t}\right) \times \\
& \log \left[\frac{\left(S_{c}\right)\left(C_{d}\right)\left(D^{0,75}-1,132\right)}{215,63(J)\left(D^{0,75}-\frac{18,42}{\left(E_{C / k}\right)^{0,25}}\right)}\right]
\end{aligned}
$$

AASHTO 93 tasarım rehberine göre beton kaplama kalınlığına (D) etki eden faktörler yukarıda denklem (1) de görüldüğü üzere aşağıdaki parametrelerdir:

- $\quad \mathrm{T}_{8,2}$ trafik yükü; belirlenen hizmet ömrü boyunca beton kaplamanın hesap şeridine düşen toplam standart (8,2 ton) dingil yükü tekerrür sayısıdır.

- $\quad \mathrm{Z}_{\mathrm{R}}$ ve $\mathrm{S}_{0}$; beton kaplamanın inşası ve hizmet süresi boyunca oluşabilecek risklere ve bilinmezliklere karşı beklenen işlevselliği gösterebilmesi amacıyla tasarım esnasında belirlenen güvenilirliğe bağlı standart ve normal sapma değerleridir.

- $\quad \Delta$ PSI Servis Kabiliyeti; yolun belirlenen yüksek hız ve hacimde kullanıcıya konforlu bir şekilde hizmet edebilme kabiliyetine bağlı olarak 0-5 arası değişen değerlerle tanımlanabilen bir ölçüttür. Yolun hizmete açıldığı durumdaki ilk servis kabiliyeti $\left(\mathrm{P}_{0}\right)$ ile performans ömrü sonundaki onarım ve takviye öncesi son servis kabiliyeti $\left(\mathrm{P}_{\mathrm{t}}\right)$ arasındaki servis kabiliyeti farkı, tasarım kalınlığının belirlenmesin de önemli rol oynamaktadır. Yolun önemi, trafik hacmi, ekonomi ve iklim, zemin koşulları gibi çevresel faktörler göz önüne alınarak üstyapının ilk servis kabiliyeti $\left(\mathrm{P}_{0}\right)$ 4,2-4,5 arasinda, son servis kabiliyeti $\left(\mathrm{P}_{\mathrm{t}}\right)$ ise 2,0-2,5 arasinda değişebilmektedir.

- Tasarıma etki eden beton karakteristik malzeme özellikleri; $E_{c}$ elastisite modülü ve $\mathrm{S}_{\mathrm{c}}$ kopma modülüdür.

- Efektif yatak modülü (k) değeri temel ve alt temelin üstyapıya sağlamış olduğu reaksiyon kuvvetinin göstergesidir. 
- Yük transferi katsayısı (J), beton kaplamada yükün derzler ve çatlaklar boyunca transfer edilmesinin bir ölçütü olarak kaplama kalınlığına etki etmektedir. Genel olarak yük transfer mekanizmalarına kayma çubuklarının olup olmamasına ya da banketlerin cinsi ve yolla bağlantı durumlarına göre 2,3-4,4 arasında değişiklik göstermektedir. Derzlerde yük transferi artıkça yük transfer katsayısı düşmektedir.

- Drenaj katsayısı $\left(\mathrm{C}_{\mathrm{d}}\right)$ da üstyapı drenaj koşullarına ve yıllık yağış miktarlarına bağlı olarak 0,7 (en kötü durum) ile 1,25 (en iyi durum) arasında değişmektedir. Genel olarak bir bilgi sahibi olunamaması durumunda etkisinin göz ardı edilmesi için 1,0 alınması önerilmektedir.

Mevcut yol için eldeki veriler incelendiğinde temel ve alt temele ait taşıma özellikleri CBR'a göre verilmesinden dolayı ilgili verinin denklem (1) içinde kullanılabilmesi için ilk olarak CBR değerlerini efektif yatak modülüne dönüştürmek gerekmekte olup bu amaçla AASHTO 2002 Tasarım Rehberinde verilen aşağıdaki denklem (2) kullanılmıştır [42].

$M R=2555 x C B R^{0,64}$

Denklem (2)'de $M R$ temel/alt temel esneklik modülü, $C B R$ ise Kaliforniya Taşıma Oranını göstermektedir. Her bir tabakanın etkisi ayrı ayrı gözüne alınarak efektif yatak modülü 1161 pci bulunmuş ve daha sonra zemin zayıflama katsayısı $(\mathrm{LS}=1,0)$ alınarak düzeltilmiş efektif yatak zemin modülü 300 pci olarak belirlenmiştir.

Proje trafiğinin AASHTO 93 Rijit Üstyapı Tasarım Rehberine göre belirlenebilmesi için ilk olarak karayolu üzerinden geçen her araca ait çeşitli dingil yükleri, standart dingil yüküne ( 8,2 ton) çevrilmesi gerekmektedir. İkinci adımda ise tüm standart dingil yüklerine ait eşdeğer standart dingil yükü tekerrür sayısı $\left(T_{8,2}\right)$ hesaplanmakta ve hesaplama yapılırken aşağıdaki denklem (3) kullanılmaktadır.

$T_{8,2}=t_{i} \times 365 \times\left(\frac{(1+r)^{t}-1}{r}\right) \times T E F \times \frac{\eta}{i}$

Burada $t_{i}$ yıllık ortalama günlük trafik sayısını, $r$ trafik artış oranını, $t$ yıl olarak süreyi, TEF taşıt eşdeğerlilik faktörünü, $\eta$ hesap şeridi faktörünü, $i$ ise trafik yönü sayısını göstermektedir. Taşıt eşdeğerlilik faktörleri $(T E F)$ karayolu üzerindeki araçlara ait çeşitli dingil yüklerini standart dingil yüküne çevirmek için kullanılan katsayılardır. TEF bulunurken AASHTO 93 Rijit Üstyapı Tasarım Rehberinde bulunan bir dizi formülasyon kullanılmaktadır [43]. Bu formülasyon sonucu elde edilen dingil eşdeğerlilik faktörü $(D E F)$, her taşıt grubuna ait dingil ağırlığı ile çarpılarak toplam taşıt sayısına bölünmesi ile taşıt eşdeğerlilik faktörünü (TEF) bulunmaktadır. Bu hesaplarda kullanılan denklem (4-8) aşağıda verilmiştir.

$$
\begin{aligned}
& \log \left(\frac{T_{x}}{T_{8,2}}\right)=4,62 \log (18+1)-4,62 \log \left(L_{x}+L_{2}\right)+3,28 \log \left(L_{2}\right)+\frac{G_{t}}{\beta_{x}}-\frac{G_{t}}{\beta_{18}} \\
& G_{t}=\log \left(\frac{4,5-P_{t}}{4,5-1,5}\right) \\
& \beta_{x}=1,00+\frac{3,63\left(L_{x}+L_{2}\right)^{5,20}}{(D+1)^{8,46} L_{2}{ }^{3,52}}
\end{aligned}
$$


$\beta_{18}=1,00+\frac{3,63(18+1)^{5,20}}{(D+1)^{8,46} 1^{3,52}}$

$T E F=\frac{T_{8,2}}{T_{x}}$

Burada; $T_{x}$ "t" y1l sonra " $x$ " dingil yükünün tekerrür sayıs1, $T_{8,2}$ ise " $\mathrm{t}$ " yıl sonra standart dingil yükü tekerrür sayısını, $L_{x}$ tek/tandem/tridem dingil üzerindeki yükün kip birimi ile gösterimini, $L_{2}$ dingil kodu (1 tek, 2 tandem, 3 tridem), $P_{t}$ son servis kabiliyeti ve $D$ beton plaka kalınlığının inç birimi ile gösterimidir. Bu çalışma için alınan Taşıı Eşdeğerlilik Faktörleri (TEF) değerleri Tablo 4’te verilmiştir [1].

Tablo 4 - AASHTO 93 Rijit Üstyapı Tasarımı için alınan Taşıt Eşdeğerlilik Faktörleri [1].

\begin{tabular}{cc}
\hline Trafik Grubu & $\begin{array}{c}\text { Taşıt Eşdeğerlilik } \\
\text { Faktörleri (TEF) }\end{array}$ \\
\hline Otomobil & 0,0006 \\
Orta yüklü ticari taşıt & 0,70 \\
Otobüs & 3,40 \\
Kamyon & 3,80 \\
Treyler & 6,60 \\
\hline
\end{tabular}

Tablo 5 - Afyon-Emirdă̆ Ayrım yolu AASHTO 93 beton plaka kalınlık tasarımı girdileri.

\begin{tabular}{lcl}
\hline $\mathrm{S}_{\mathrm{c}}$ & $600(\mathrm{psi})$ & Beton Kopma Dayanımı \\
$\mathrm{E}_{\mathrm{c}}$ & $4.200 .000(\mathrm{psi})$ & Beton Elastisite Modülü \\
$\mathrm{k}$ & $300(\mathrm{psi} / \mathrm{in})$ & Efektif Yatak Zemin Modülü \\
$\mathrm{Z}_{\mathrm{R}}$ & $85-90-95-99(\%)$ & Güvenilirlik \\
$\mathrm{S}_{\mathrm{o}}$ & 0,35 & Standart Sapma \\
$\mathrm{J}$ & 2,8 & Yük Taşıma Katsayısı \\
$\mathrm{C}_{\mathrm{d}}$ & 1 & Drenaj Katsayısı \\
$\mathrm{P}_{0}$ & 4,2 & İlk Servis Kabiliyeti \\
$\mathrm{P}_{\mathrm{t}}$ & 2,5 & Son Servis Kabiliyeti \\
$\Delta \mathrm{PSI}$ & 1,7 & Servis Kabiliyeti Farkı \\
$\mathrm{t}_{\mathrm{i}}$ & 4046 & Yıllık Ortalama Günlük Trafik (YOGT) \\
$\mathrm{r}$ & $3-5-8(\%)$ & Trafik Artış Oranı \\
$\eta$ & 0,80 & Hesap Şeridi Faktörü \\
$\mathrm{i}$ & 2 & Trafik Yönü Sayısı \\
\hline
\end{tabular}


Proje trafiğinin belirlenmesi ile deneme kesimine ait beton kaplama kalınlığ 1 tasarımı, AASHTO 93 Rijit Üstyapı Tasarım Rehberine göre yola ait mevcut veriler (Tablo 5) kullanılarak yapılmıştır.

$\mathrm{Bu}$ çalışmada, yolun trafiğe açılması ile uygulanması planlanan ilk takviye tabakasına kadar geçen zamanki aralığını temsil eden proje süresi 20 yıl; tüm bakım onarım ve takviye tabakalarını içeren ve yolun üstyapı ömrünü tamamlaması neticesiyle biten ve literatürde analiz süresi olarak belirtilen zaman dilimi ise 30 yıl olarak seçilmiştir. Ancak bu çalışmanın amacı mevcut yola ait ilk tasarım kalınlıklarının farklı tasarım yöntemlerine göre karşılaştırması olduğu için analiz süresi içerisindeki kademeli inşaat projesi ve tabaka takviyesi bu çalışma kapsamı dışına çıkmaktadır. Buna rağmen, bu çalışmada proje süresi hem 20 yıl için hem de proje süresi analiz süresine eşit alınarak 30 yıl esas alınarak proje trafiği belirlenmiştir.

AASHTO 93 Rijit Üstyapı Tasarım Rehberine göre Tablo 5 'te bulunan verileri denklem (1) de kullanarak, iki farklı proje süresi (20 ve 30 yıl), üç farklı trafik artış yüzdesi ( $\% 3, \% 5$ ve \%8) ve buna bağlı olarak üç farklı eşdeğer standart dingil yükü tekerrür sayısı $\left(T_{8,2}\right)$ hesaplanarak, dört farklı güvenilirlik düzeyinde $(\% 85, \% 90, \% 95, \% 99)$ toplamda 24 farklı durum için beton kaplama tasarım kalınlığı yapılarak Tablo 6'da verilmiştir. Tablodan da görüleceği üzere hesaplanan beton plaka kalınlıkları, mevcuttaki $27 \mathrm{~cm}$ beton plaka kalınlarından hem 20 yıllık hem de 30 yıllık servis süreleri için daha yüksek bulunmuştur. Dolayısıyla, Belçika Katalog yöntemine göre hesaplanan 27 cm'lik kalınlık, AASHTO 93'e göre daha düşük bulunmaktadır.

Tablo 6 - AASHTO 93 ile hesaplanan Afyon-Emirdăg Ayrım yolu beton plaka kalınlıklarl.

\begin{tabular}{|c|c|c|c|c|c|}
\hline \multirow{3}{*}{ Güvenilirlik } & \multirow{3}{*}{$\begin{array}{l}\text { Trafik Artış } \\
\text { Yüzdesi }\end{array}$} & \multicolumn{4}{|c|}{ Proje Süresi } \\
\hline & & \multicolumn{3}{|c|}{$20 \mathrm{y} 1 \mathrm{l}$} & \multirow{2}{*}{$\begin{array}{c}30 \text { yıl } \\
\begin{array}{c}\text { Tasarım kalınlığ } \\
(\mathrm{cm})\end{array}\end{array}$} \\
\hline & & $\begin{array}{l}\text { ESAL } \\
\left(T_{8,2}\right)\end{array}$ & $\begin{array}{l}\text { Tasarım kalınlığ } 1 \\
(\mathrm{~cm})\end{array}$ & $\begin{array}{l}\text { ESAL } \\
\left(T_{8,2}\right)\end{array}$ & \\
\hline$\% 85$ & \multirow{4}{*}{$\% 3$} & \multirow{4}{*}{29.963 .386} & 28 & \multirow{4}{*}{53.057 .607} & 31 \\
\hline$\% 90$ & & & 29 & & 32 \\
\hline$\% 95$ & & & 31 & & 33 \\
\hline$\% 99$ & & & 33 & & 35 \\
\hline$\% 85$ & \multirow{4}{*}{$\% 5$} & \multirow{4}{*}{36.877 .155} & 29 & \multirow{4}{*}{74.088 .848} & 33 \\
\hline$\% 90$ & & & 30 & & 34 \\
\hline$\% 95$ & & & 32 & & 35 \\
\hline$\% 99$ & & & 34 & & 38 \\
\hline$\% 85$ & \multirow{4}{*}{$\% 8$} & \multirow{4}{*}{51.028 .081} & 31 & \multirow{4}{*}{126.321 .263} & 35 \\
\hline$\% 90$ & & & 32 & & 36 \\
\hline$\% 95$ & & & 33 & & 38 \\
\hline$\% 99$ & & & 35 & & 41 \\
\hline
\end{tabular}




\section{MEKANISTIK AMPIRIK (M-E) ÜSTYAPI TASARIMI}

Çalışmanın bu kısmında mevcut beton yolun özellikleri kullanılarak AASHTOWare 2.0 sonlu elemanlar yöntemi ile yüzeydeki zamana karşı oluşacak bozulmalar, üstyapı performansı, analiz edilmiştir. Öztürk vd. [7] tarafından yapılan bir çalışmada ayrıntılı olarak ele alındığı üzere, bu yeni tasarım yöntemini diğer ampirik yöntemlerden ayıran en önemli özellik, tasarımın mekanik kısmını oluşturan trafik yüklerine ve çevresel koşullara bağlı olarak üstyapıda meydana gelecek gerilme, birim şekil değiştirme ve deformasyonların hesaplanabilmesidir. M-E tasarım yönteminin diğer yöntemlerden ayıran diğer önemli bir özelliği ise tasarım girdilerinin daha gerçekçi ve ayrıntılı bir şekilde tanımlanmasıdır. Özellikle trafik yüklerinin belirlenmesi için diğer yöntemlerden farklı olarak eşdeğer standart dingil yükü (ESAL) yaklaşımı yerine daha gerçekçi, her araca özel tam spektrumlu dingil yüklerinin ayrı ayrı tanımlanabilmesidir. Malzeme karakteristik özelliklerinin belirlenebilmesi için diğer yöntemlerdeki beton elastisite ve kopma modülünden farklı olarak ayrıca çekme dayanımı, basınç dayanımı, poisson oranı, termal genleşme katsayısı, birim hacim ağırlığ ve rötre birim şekil değiştirmesi gibi betonun karakteristik özellikleri de kullanılmaktadır.

Ayrıca, çevresel etkilerin performansa etkisinin hesaplanabilmesi için detaylı bir iklim verisinin kullanılması gerekmektedir. Tüm bu veriler, çalışmanın önemi ve mevcut veri detayına bağlı olarak program içerisinde üç seviyede (Seviye 1-2-3) tanımlanmıştır. Seviye 1 'deki tasarım girdilerini zeminler için saha deney sonuçlarını, üstyapı beton malzemesi için ise laboratuvar testleri sonuçlarından elde edilen veriler oluşturmaktadır. Seviye 1 girdileri daha gerçekçi sonuçlar vermesine rağmen elde edilmesi uzun zaman almaktadır ve yüksek maliyetlidir. Seviye 2'deki tasarım girdileri yerel olarak kalibre edilmiş korelasyon denklemleri yardımıyla elde edilen verilerdir. Seviye 3'teki tasarım girdileri ise M-E tasarım kataloğunda önerilen standart tasarım verileridir. Seviye 3 'teki veriler daha çoğunlukla ABD ve Kanada'da dışında yerel kalibrasyonun henüz tamamlanmadığı ülkelerde genel olarak tercih edilmektedir [14-25,33]. Ülkemizde henüz kalibrasyon çalışması olmadığı için bu çalışma kapsamında Seviye 3 tasarım verileri kullanılmıştır.

$\mathrm{Bu}$ çalışmada, Afyon-Emirdağ deneme kesimine ait beton yol tasarım verileri (Tablo 1) program girdisi olarak kullanılmışır. Ayrıca, M-E tasarım yöntemini diğer ampirik yöntemlerden ayıran en önemli hususlardan bir diğeri ise iklim etkisidir. Buna ilişkin tasarımda ihtiyaç duyulan veriler ise yolun yapılacağı bölgeye ait günlük, aylık ve yıllık sıcak değerleri, yağış miktarları, rüzgâr hızları, nem ve güneş ışığı yüzdeleridir. ABD ve Kanada dışında bu verilere sahip ülkeler henüz bulunmadığı için bu ülke dışında M-E tasarımı yapılan çalışmalarda ABD eyaletlerine ait eşdeğer iklim verileri kullanılmıştır [15,16,20,22,25]. Bu çalışma kapsamında da Afyon-Emirdağ Ayrım yolu M-E beton yol tasarımında yapılan eşleştirmeler neticesinde eşdeğer iklim verisi için Afyonkarahisar bölgesi için eşleştirilen Spokane WA istasyon verileri kullanılmıştır [7]. Eşleştirmede yıllık ortalama minimum kış ayı sıcaklığı, yıllık ortalama maksimum yaz ayı sıcaklığı, yıllık ortalama ilkbahar ve sonbahar sıcaklık, yıllık ortalama sıcaklık ve yıllık ortalama yağış verileri ve yükseklik açısından benzerlik saptanan istasyonlar ön eşleşmeye tabi tutulmuş ve son eşleştirmede ise yıllık ortalama günlük güneşlenme şiddeti, ortalama rüzgâr hızı ve ortalama bağıl nem dikkate alınmıştır. 
Mekanistik-Ampirik ve Geleneksel Beton Yol Tasarım Yöntemlerinin ...

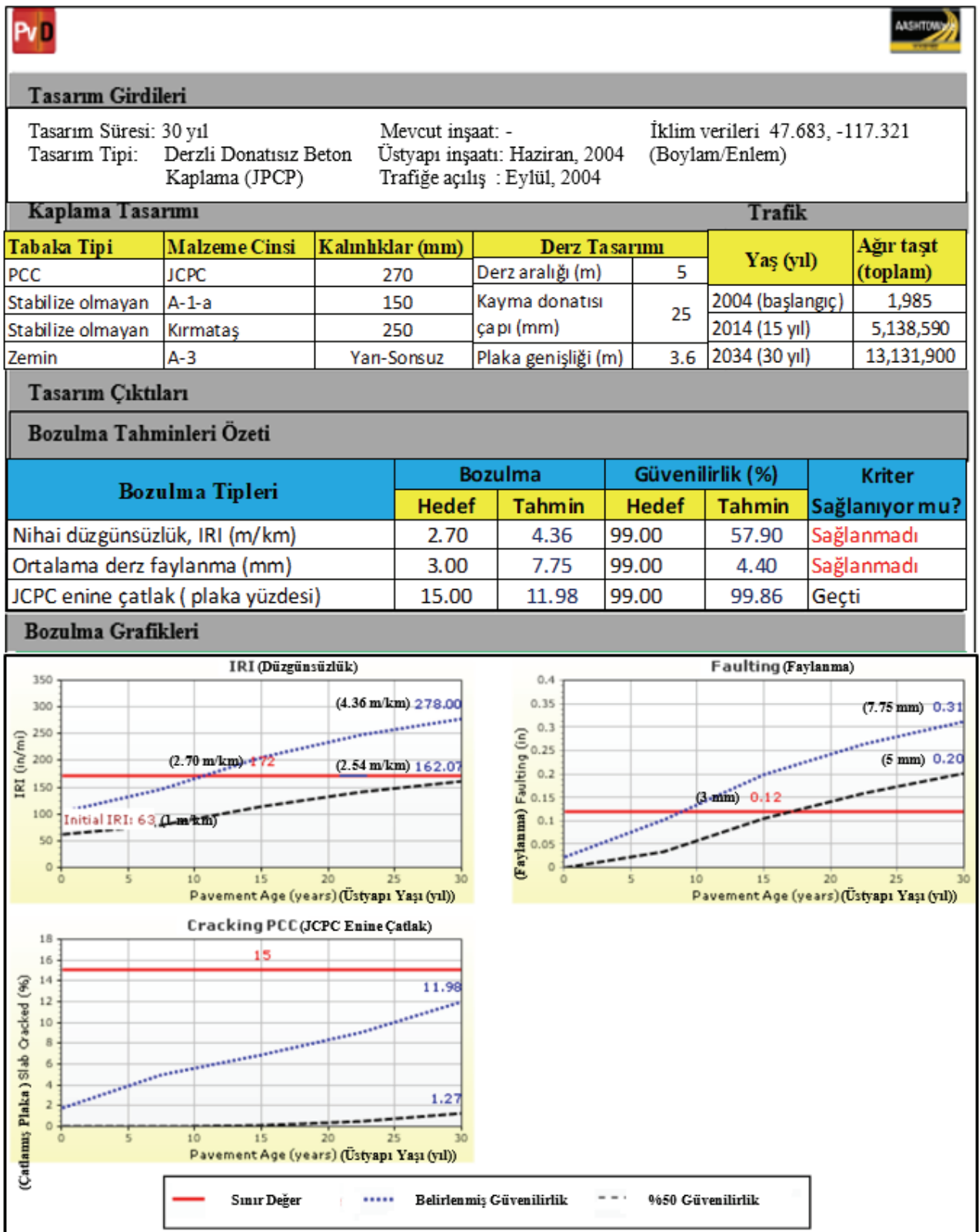

Şekil 3 - M-E analizleri ile \%99 güvenilirlik ve \%5 trafik artışı için 30 yıllık performans süresi sonunda Afyon-Emirdăg Beton Yolu Performans Değerleri (Türkçeye çevrilmişs program çıktısı). 
Tablo 7 - M-E tasarımı ile mevcut yola ait performans analizi.

\begin{tabular}{|c|c|c|c|c|c|c|c|c|}
\hline \multirow[b]{3}{*}{$\begin{array}{l}\text { Güvenirlilik } \\
\text { (\%) }\end{array}$} & \multirow[b]{3}{*}{ Bozulma Tipleri } & \multirow{3}{*}{$\begin{array}{l}\text { Bozulma Tipi } \\
\text { Limit } \\
\text { Değerleri }\end{array}$} & \multicolumn{6}{|c|}{ Trafik Artış Hızı } \\
\hline & & & & $3 \%$ & & & $5 \%$ & \\
\hline & & & $\begin{array}{c}30 \text { yil sonra } \\
\text { hesaplanan } \\
\text { değer }\end{array}$ & $\begin{array}{c}\text { Kriter } \\
\text { Sağllyor Mu? }\end{array}$ & $\begin{array}{l}\text { Limit Değere } \\
\text { Ulaşma Yilı }\end{array}$ & $\begin{array}{c}30 \text { yil sonra } \\
\text { hesaplanan } \\
\text { değer }\end{array}$ & $\begin{array}{c}\text { Kriter } \\
\text { Sağllyor Mu? }\end{array}$ & $\begin{array}{l}\text { Limit Değere } \\
\text { Ulaşma Yllı }\end{array}$ \\
\hline \multirow{4}{*}{85} & Nihai & & & & & & & \\
\hline & $\begin{array}{l}\text { Düzgünsüzlük } \\
\text { (IRI) m/km }\end{array}$ & 2,7 & 3,2 & $\mathbf{X}$ & 21 & 3,4 & $\mathbf{X}$ & 17 \\
\hline & $\begin{array}{l}\text { Ortalama Derz } \\
\text { Faylanması } \\
(\mathrm{mm})\end{array}$ & 3 & 5,8 & $\mathbf{X}$ & 14 & 6,3 & $\mathbf{X}$ & 12 \\
\hline & $\begin{array}{l}\text { Enine Catlak } \\
\text { Görülen Plaka } \\
\text { Yüzdesi }\end{array}$ & 15 & 5,2 & $\checkmark$ & $>\mathbf{3 0}$ & 6,0 & $\checkmark$ & $>\mathbf{3 0}$ \\
\hline \multirow{3}{*}{90} & $\begin{array}{c}\text { Nihai } \\
\text { Düzgünsüzlük } \\
\text { (IRI) } \mathrm{m} / \mathrm{km}\end{array}$ & 2,7 & 3,4 & $\mathbf{X}$ & 17 & 3,5 & $\mathbf{X}$ & 16 \\
\hline & $\begin{array}{l}\text { Ortalama Derz } \\
\text { Faylanmas1 } \\
(\mathrm{mm})\end{array}$ & 3 & 6,0 & $\mathbf{X}$ & 12 & 6,5 & $\mathbf{X}$ & 11 \\
\hline & $\begin{array}{l}\text { Enine Catlak } \\
\text { Görülen Plaka } \\
\text { Yüzdesi }\end{array}$ & 15 & 6,2 & $\checkmark$ & $>\mathbf{3 0}$ & 7,2 & $\checkmark$ & $>\mathbf{3 0}$ \\
\hline \multirow{3}{*}{95} & $\begin{array}{l}\text { Nihai } \\
\text { Düzgünsüzlük } \\
\text { (IRI) } \mathrm{m} / \mathrm{km}\end{array}$ & 2,7 & 3,6 & $\mathbf{X}$ & 15 & 3,8 & $\mathbf{X}$ & 13 \\
\hline & $\begin{array}{l}\text { Ortalama Derz } \\
\text { Faylanmasi } \\
(\mathrm{mm})\end{array}$ & 3 & 6,5 & $\mathbf{X}$ & 11 & 7,0 & $\mathbf{X}$ & 10 \\
\hline & $\begin{array}{l}\text { Enine Catlak } \\
\text { Görülen Plaka } \\
\text { Yüzdesi }\end{array}$ & 15 & 7,7 & $\checkmark$ & $>\mathbf{3 0}$ & 8,8 & $\checkmark$ & $>\mathbf{3 0}$ \\
\hline \multirow{3}{*}{99} & $\begin{array}{c}\text { Nihai } \\
\text { Düzgünsüzlük } \\
\text { (IRI) } \mathrm{m} / \mathrm{km}\end{array}$ & 2,7 & 4,1 & $\mathbf{X}$ & 11 & 4,4 & $\mathbf{X}$ & 10 \\
\hline & $\begin{array}{l}\text { Ortalama Derz } \\
\text { Faylanmas1 } \\
(\mathrm{mm})\end{array}$ & 3 & 7,3 & $\mathbf{X}$ & 9 & 7,8 & $\mathbf{X}$ & 8 \\
\hline & $\begin{array}{c}\text { Enine Çatlak } \\
\text { Görülen Plaka } \\
\text { Yüzdesi }\end{array}$ & 15 & 10,5 & $\checkmark$ & $>\mathbf{3 0}$ & 12,0 & $\checkmark$ & $>\mathbf{3 0}$ \\
\hline
\end{tabular}

$\% 3$ ve $\% 5$ olmak üzere iki farklı trafik artı̧̧ yüzdesi ile \%85-\%90-\%95 ve \%99 olmak üzere dört farklı güvenilirlik düzeyi için ayrı ayrı gerçekleştirilerek toplamda sekiz analiz yapılmıştır. Analizler sırasında, yol geçişi boyunca $27 \mathrm{~cm}$ 'lik minimum beton plaka kalınlığ 1 sabit tutulmuştur. Yeğinobalı [2] tarafından belirtilen ve bazı bölgelerde gerekli yol kotunun sağlanması için $30 \mathrm{~cm}$ 'e kadar artırılan plaka kalınlığı ve 1,5 cm'lik sathi kaplama analizlerde dikkate alınmamıştır. Analizlerde M-E tasarımın performans tahmini yapması için gerekli olan limit değerler; yüzey düzgünsüzlüğü için $2,7 \mathrm{~m} / \mathrm{km}$, faylanma için $3 \mathrm{~mm}$ ve enine çatlaklar için \%15 performans değerleri sınır değerler olarak kabul edilmiştir. Bu değerler, AASHTO tarafindan önerilen tipik değerlerdir. Tipik bir analiz özeti Şekil 3 'te gösterilmiştir. $\mathrm{Bu}$ analizden de görüleceği üzere 30 yıllık bir tasarım süresi ve $\% 99^{\prime} l u k$ güvenilirlik için hedeflenen $2,70 \mathrm{~m} / \mathrm{km}$ 'lik IRI (Uluslararası Düzgünsüzlük İndeksi), 3 mm'lik ortalama derz faylanması ve plakaların \%15'inde enine çatlak oluşması durumu M- 
E analizi sonucunda sırasıyla 4,36 m/km, 7,75 mm ve \%11,98 olarak hesaplanmıştır. Bu durumda da beton yol 30 yıllık tasarım süresi sonrasında yüzey düzgünsüzlüğü ve derz faylanması performans kriterlerini sağlayamayacak, enine çatlama performans kriterini ise sağlayabilecektir.

$\mathrm{Bu}$ şekilde yapılan M-E performans analizlerinin sonuçları Tablo 7'de özetlenmiştir. $\mathrm{Bu}$ tablodan da görüleceği üzere, $27 \mathrm{~cm}$ beton plaka kalınlığına ve $5 \mathrm{~m}$ derz aralığına sahip mevcut yolun 30 y1llık servis süresi içinde her durumda yüzey düzgünsüzlügü ve derz faylanması performans sınır değerlerini aşacağı, ancak enine çatlak performans sınır değerleri içerisinde kalacağı tespit edilmiştir (Tablo 7).

\section{DEĞERLENDİRME}

Mevcut deneme kesiminin AASHTO 93 ile yapılan analizlere göre hem trafik artış yüzdesinden hem de güvenilirlikten bağımsız olarak beton plaka kalınlığı için mevcuttaki 27 cm'den daha kalın sonuçlar elde edilmiştir. Seçilen güvenilirlik yüzdesine bağlı olarak önerilen plaka kalınlığının 4-5 cm değişebildiği sonucuna varılmıştır. Ayrıca trafik artış yüzdesinin de plaka kalınlığını 1-2 cm değiştirdiği gözlemlenmiştir. Tasarım ömrünün 20 yıldan 30 yıla çıkarılması plaka kalınlığında 2-6 cm artışa sebep olduğu ayrıca göz önüne alınmalıdır. Bu bağlamda 20 yıllık bir tasarım ömrü ile yapılan tasarımı ve 20 yılın ardından yapılacak bir bakım-onarım ile toplam servis ömrünün 30 yıla çıkarılması veya 30 yıllık bir tasarım ömrü ile yapılan bir dizaynın ekonomik girdileri ve çıktıları ayrıca ele alınmalıdır.

Belçika Katalog Yöntemi ile üstyapı tasarımı gerçekleştirilirken proje trafik sınıfının B2(<65 Milyon ESAL $100 \mathrm{kN}$ ) olarak öngörüldüğü bilinmektedir [2]. Benzer trafik yük miktarına sahip olan tasarım Tablo 6'ya göre, 30 yıl tasarım ömrü ve $\% 5$ trafik artış yüzdesi ile yaklaşık 75 Milyon ESAL $80 \mathrm{kN}$ olan tasarımdır. Plaka tasarım kalınlıkları \%85, \%90, \%95 ve \%99 güvenilirlik için sırasıyla 33, 34, 35 ve $38 \mathrm{~cm}$ olarak hesaplanmıştır. KGM tarafından Esnek Üstyapı Tasarım Rehberinde [45] devlet yolları için belirtilen \%85'lik güvenilirlik düzeyinin rijit üstyapılar için de aynı olduğu varsayılırsa plaka kalınlığının AASHTO 93 yöntemine göre mevcuttan $5 \mathrm{~cm}$ kalın olacak şekilde $33 \mathrm{~cm}$ olarak seçilmesi gerekmektedir. Fakat, bu noktada Afyon Emirdağ yol ayrımında 2004 yılından itibaren öngörülemeyen oranda ağır taşıt trafiğinde artış olduğu tahmin edilmektedir. Bu çalışmada da gerçek trafik artış değerleri kullanılması sebebiyle tasarım kalınlıkları daha yüksek çıkmaktadır.

$\mathrm{Bu}$ çalışmanın ikinci aşamasında ise, mevcut Afyon Emirdağ beton yolu için AASHTO tarafından önerilen hedef bozulma değerlerine kaçıncı yılda ulaşılacağı ve saha ölçümlerinden elde edilen performans değerleri ile M-E tasarım yönteminden elde edilen performans çıtılarının karşılaştırılması yapılmıştır. Beklenildiği üzere tasarımda güvenilirlik yüzdesi artırıldıkça tahmin edilen bozulma suresinde kısalma olmaktadır. Program çıktıları incelendiğinde tahminler arasında on yıla varan farklılıklar olduğu gözlemlenmiştir. Ayrıca analiz sonuçlarına göre yüzey düzgünsüzlüğünün ve derz faylanmasının daha kritik bozulmalar olduğu görülmektedir.

Bu çalışma kapsamında ayrıca M-E tasarım yönteminin işlevselliği, gerçekçiliği ve lokal kalibrasyonu adına M-E tasarım yönteminden elde edilen performans çıktıları ile halihazırdaki yola ait KGM tarafından ölçülen gerçek saha performans değerlerinin karşılaştırılması önemli olacaktır. Ancak Tablo 2'den de görüldüğü üzere mevcut yol 
üzerinden KGM tarafından ölçülen farklı yıllara ait performans parametreleri ile M-E tasarım yönteminden elde edilebilen performans parametreleri karşılaştırıldığında ortak tek bir parametrenin yani IRI değerinin mevcut olduğu görülmektedir. Halihazırdaki yol için derz faylanması ve enine çatlak yüzdesine ait saha ölçümleri mevcut değildir. Diğer taraftan M-E tasarım yönteminde de SN değeri ve yol yüzeyi ortalama yapı derinliği performans çıktıları bulunmamaktadır. Bundan dolayı mevcut yola ait saha ölçüm performans değerleri ile M-E tasarım yönteminden elde edilen performans çıktılarından sadece IRI değeri karşılaştırabilmektedir. Ancak burada IRI değerinin üstyapı tasarımında kullanılan hizmet düzeyi (PSI) ile doğrudan ilişkili olduğu göz önüne alınırsa [46-48] ve ayrıca üstyapı performansının değerlendirilmesi için tek bir indeksin kullanılmasının benimsendiği çalışmalarda düzgünsüzlüğün tercih edildiği düşünülürse [35] yapılacak bu karşılaştırmanın da ne kadar önemli olduğu anlaşılmaktadır.

Halihazırdaki yola ait KGM tarafından ölçülen farklı yıllara ait saha ölçüm IRI değerleri ile M-E tasarım yöntemi performans çıktısı IRI değerleri Tablo 8'de verilmiştir.

\section{Tablo 8 - Afyon-Emirdağ Ayrım Yolu IRI saha ölçümlerinin ve M-E tahminlerinin karşılaştırılması.}

\begin{tabular}{|c|c|c|c|c|c|c|c|c|c|}
\hline \multirow{4}{*}{ Yillar } & \multirow{4}{*}{$\begin{array}{c}\text { IRI Saha } \\
\text { Ölçümleri } \\
{[1]}\end{array}$} & \multicolumn{8}{|c|}{ IRI M-E Sonlu Elemanlar Tahmini } \\
\hline & & \multicolumn{4}{|c|}{ \% 3 Trafik Artışı } & \multicolumn{4}{|c|}{$\% 5$ Trafik Artışı } \\
\hline & & \multicolumn{4}{|c|}{ Güvenilirlik Düzeyi } & \multicolumn{4}{|c|}{ Güvenilirlik Düzeyi } \\
\hline & & $\% 85$ & $\% 90$ & $\% 95$ & $\% 99$ & $\% 85$ & $\% 90$ & $\% 95$ & $\% 99$ \\
\hline 2005 & 1,67 & 1,32 & 1,38 & 1.52 & 1,70 & 1,32 & 1,40 & 1,50 & 1,70 \\
\hline 2006 & 1,78 & 1,34 & 1,43 & 1,55 & 1,74 & 1,35 & 1,44 & 1,53 & 1.76 \\
\hline 2007 & 1,79 & 1,39 & 1,46 & 1,60 & 1,81 & 1,40 & 1,48 & 1,60 & 1,81 \\
\hline 2008 & 1,82 & 1,45 & 1,52 & 1,66 & 1,88 & 1,47 & 1,54 & 1,66 & 1,90 \\
\hline 2009 & 1,90 & 1,50 & 1,60 & 1,74 & 1,97 & 1,52 & 1,60 & 1,73 & 1,98 \\
\hline 2012 & 1,98 & 1,73 & 1,83 & 2,01 & 2,31 & 1,77 & 1,89 & 2,05 & 2,36 \\
\hline
\end{tabular}

Şekil 4'ten de görüldüğü üzere \%99 güvenilirlik düzeyi için M-E AASHTOWare 2.0 Sonlu elemanlar yöntemi ile tahmin edilen IRI değerleri ve gerçek saha ölçümlerinden elde edilen değerler birbirine oldukça yakındır. Bu nedenle bu çalışmada Tablo 8'de \%99 güvenilirlik düzeyi için tahmin edilen bozulma değerlerinin daha gerçekçi olduğu tespit edilmiştir. $\mathrm{Bu}$ sebeple 30 yıllık servis ömrünün sonunda hiçbir bakım onarım yapılmaması halinde yaklaşık $4 \mathrm{~m} / \mathrm{km}$ nihai düzgünsüzlük ve derzlerde $7 \mathrm{~mm}$ faylanma olması öngörülmektedir. Hâlihazırda yol yüzeyinde malzeme kaynaklı bazı çatlaklar gözlemlenmiş olup derzlerde faylanma henüz oluşmamıştır. Fakat elimizdeki açık veri kaynağı 2012 yılına kadar olduğu için sadece 2005-2012 yılları arasındaki sınırlı veri kullanılarak yukarıdaki öngörülerde bulunulmuştur. AASHTO 93 tasarım sonuçları da göz önüne alınarak beton plaka kalınlığının hem 20 hem de 30 yıllık servis ömürleri için yetersiz olduğu sonucuna varılmıştır. 


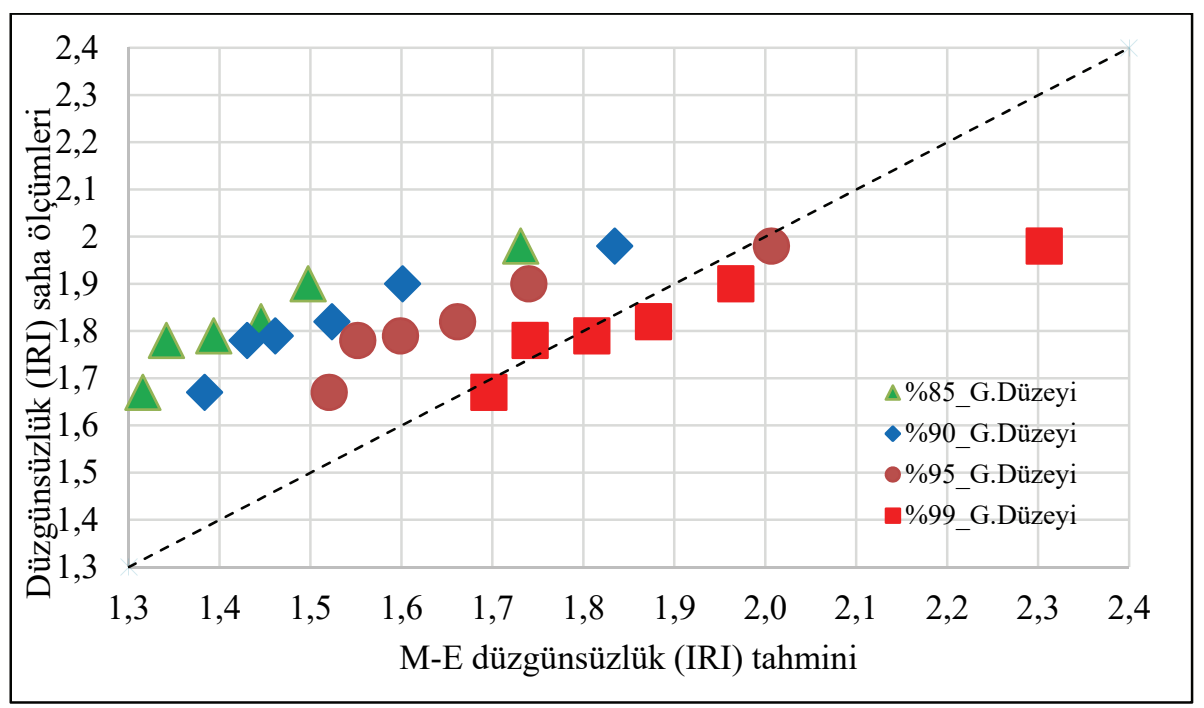

(a) \%3 trafik artışı

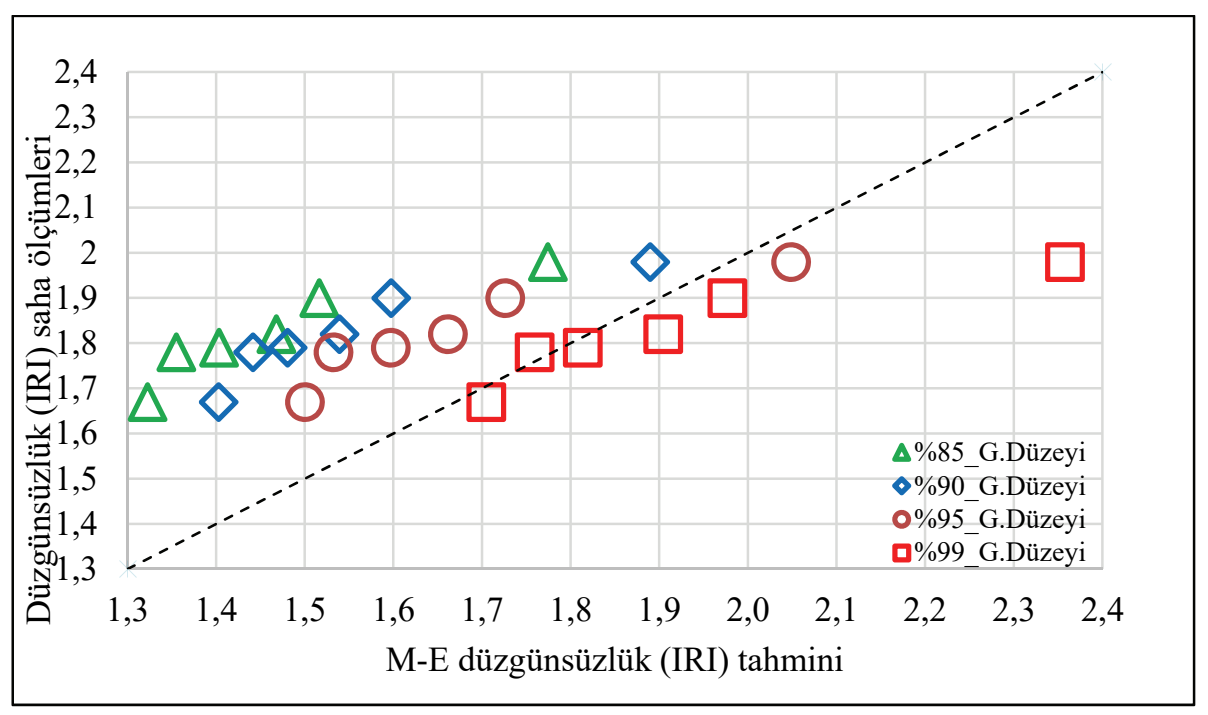

(b) $\% 5$ trafik artışı

Şekil 4 - Afyon-Emirdă̆ ayrımı ölçüme dayalı ve M-E analizi tahmini IRI değerlerinin korelasyonu.

\section{SONUÇLAR VE ÖNERILER}

Türkiye'nin ilk beton yolu olma özelliğine sahip Afyon Emirdağ Ayrımı 5+700 - 7+700 km'leri arası deneme kesimi Belçika katalog yöntemi ile $27 \mathrm{~cm}$ beton plaka kalınlığı ile üst 
yapı tasarımı gerçekleştirilmiş olup 2004 yılında trafiğe açılmıştır. Bu çalışmada farklı trafik artış oranları ve farklı güvenilirlik düzeyleri ile aynı trafik yükü, zemin koşulları, temel kalınlıkları, üstyapı malzeme özellikleri dikkate alınarak AASHTO 93 ampirik yöntemi ile tasarlanmış ve yeni nesil mekanistik ampirik yöntemi (M-E) kullanılarak halihazırdaki yola ait tasarım analiz edilerek, yerel kalibrasyon çalışmalarına öncülük etmesi açısından mevcut ve tahmin edilen düzgünsüzlük değerleri karşılaştırılmıştır. Elde edilen bulgular neticesinde;

- Yaygın olarak tercih edilen üstyapı tasarım yöntemlerinin başında gelen AASHTO 93 ampirik yöntemi ile yapılan tasarımlarda hem trafik artış yüzdesinden hem de güvenilirlikten bağımsız olarak beton plaka kalınlığı için mevcuttaki $27 \mathrm{~cm}$ 'den daha yüksek sonuçlar elde edilmiştir. \%5'lik trafik artış oranı için halihazırdaki yolun $29 \mathrm{~cm}$ beton plaka kalınlığı ile 20 yıllık proje süresinin, $33 \mathrm{~cm}$ beton kalınlığ ile de 30 yıllık proje süresinin sağlanabileceği öngörülmüştür. Bunun bir sebebinin de bu yol kesiminde öngörülemeyen oranda gerçekleşen ağır taşıt trafiği artışı olduğu tahmin edilmektedir.

- M-E tasarım yöntemi ile hâlihazırdaki beton yolun performans tahmini yapılmış ve bu koşullarda güvenilirlik düzeyine bağlı olarak yüzey düzgünsüzlüğü açısından ortalama 14. yıldan itibaren, derz faylanması nedeniyle de ortalama 10. yıldan itibaren performans kriterlerine göre sınır değerleri aşacağı, ancak çatlak yönünden 30 yıl süresince sınır değerler içinde kalacağ 1 öngörülmüştür. Her iki yöntem birlikte göz önünde bulundurulduğunda beton plaka kalınlığının hem 20 hem de 30 yıllık servis ömürleri için ince olduğu sonucuna varılmıştır.

- $\quad$ M-E tasarım yönteminden elde edilen 1. yı1, 2. yı1, 3. yı1, 4. yı1, 5. yıl ve 8. y1l IRI tahmini performans değerleri sahada ölçülen IRI değerleri karşılaştırıldığında güvenilirlik düzeyleri artıkça düzgünsüzlük değerlerinin gerçek saha değerlerine daha çok yaklaştığı görülmüştür. \%99'luk güvenilirlik düzeyi için en yakın sonuçlar elde edilmiştir (Şekil 4). Bu da yeni nesil M-E yönteminin daha kısıtlı şartlara sahip ampirik yöntemlere göre saha koşullarını daha iyi temsil ederek üstyapı tasarımını gerçekleştirebileceğini göstermektedir. Ancak daha önce de belirtildiği üzere, M-E tasarımlarının daha gerçekçi sonuçlar verebilmesi ve bozulma tahminlerini daha doğru yapabilmesi adına her ülke/eyalet/bölge/şehir bazında yerel kalibrasyon gerekmektedir. Ülkemizde ise beton yol uygulamasının oldukça kısıtlı olması ve var olan beton yolların da belediyeler tarafindan uygulanması neticesinde bu şartlar altında sağlıklı verilere ulaşılabilmenin pek de mümkün olunamaması nedeniyle sadece çalışmada incelenen mevcut deneme kesimi için karşılaştırma yapılabilmiştir.

Ülkemizde henüz tecrübe edilmeyen ve dünyada $\mathrm{ABD}$ başta olmak üzere gelişmiş bazı ülkelerde yeni yeni kullanıma geçen ancak birçok ülke tarafından uygulanabilirliği için ön araştırma çalışmaları devam eden yeni nesil M-E yol üstyapı tasarım yöntemi, kullanımında uzmanlık gerektirmesi ve diğer yöntemlere göre daha fazla veriye ihtiyaç duymasına rağmen hem daha gerçekçi tasarımlar yapılabilmesi, hem de yol üstyapı hizmet ömrü boyunca yapısal ve performans ölçütleri açısından görülebilecek deformasyonları tahmin edebilmesi açısından oldukça önemli ve gerçekçi bir tasarım yöntemidir. Ülkemizde de KGM tarafından bir beton yol projelendirme rehberi hazırlanması ve bunu yaparken M-E tasarım yöntemini de referans alması önemlidir. Ayrıca diğer yöntemlerden farklı olarak M-E tasarımı için kalibrasyon seçeneği mevcuttur ve bu da bölgesel deneyimlerin, malzeme özelliklerinin ve 
iklim koşullarının daha hassas bir şekilde tasarıma dahil edilmesini sağlamaktadır. Sonuç olarak, bu çalışma bir taraftan ülkemiz adına oluşturulması düşünülen beton yol projelendirme rehberi hazırlama sürecine bilgi birikimi olarak bir altlık oluştururken, diğer taraftan M-E tasarım yönteminin ülkemize uyarlanması için gerekli ilk basamağı oluşturan yerel kalibrasyonun yapılması adına bir başlangıç teşkil etmektedir.

\section{Semboller}

AASHTO Amerikan Devlet Karayolu ve Taşımacılık İdareleri Birliği

AASHTO 93 Amerikan Devlet Karayolu ve Taşımacılık İdareleri Birliği 1993 Üstyapı Tasarım Rehberi

ABD

Amerika Birleşik Devletleri

ACPA

Amerikan Beton Yollar Birliği

$\mathrm{C}$

Beton basınç dayanım sınıfı

CBR Kaliforniya Taşıma Oranı

$\mathrm{C}_{\mathrm{d}} \quad$ Drenaj katsayıs

D Beton kaplama kalınlığ

$\mathrm{E}_{\mathrm{c}} \quad$ Beton elastisite modülü

FEBELCEM Belçika Çimento Birliği

FHWA ABD Ulusal Karayolları İdaresi

IRI Uluslararası Düzgünsüzlük İndeksi

J Yük transfer katsayısı

$\mathrm{k} \quad$ Zemin yatak katsayısı

KGM Karayolları Genel Müdürlüğü

LS Zemin zayıflama katsayısı

M-E Mekanik-Ampirik Tasarım

MEPDG Mekanik Ampirik Üstyapı Tasarım Rehberi

MR Esneklik modülünü

NCHRP Amerika Birleşik Devletleri Ulusal Karayolları Araştırma Programı

$\mathrm{p}_{\mathrm{i}} \quad$ İlk servis kabiliyeti

$\mathrm{p}_{\mathrm{t}} \quad$ Son servis kabilyeti

$\mathrm{S}_{0} \quad$ Normal sapma

$\mathrm{S}_{\mathrm{c}} \quad$ Beton kopma modülü

SN Kayma direnci 


$\begin{array}{ll}\text { TÇMB } & \text { Türkiye Çimento Müstahsilleri Birliği } \\ Z_{\mathrm{R}} & \text { Standart sapma } \\ \text { YOGT } & \text { Yıllık ortalama günlük trafik } \\ \varnothing & \text { Donatı çapı } \\ \mathrm{W}_{18} & \text { Eşdeğer standart trafik dingil yükü } \\ \Delta \text { PSI } & \text { Servis kabiliyeti farkı }\end{array}$

\section{Teşekkür}

M-E tasarım yöntemi ile yapılan analizler için kullanılan AASHTOWare 2.0 sonlu elemanlar yazılım programının lisans alma sürecinde maddi katkılarından dolayı TÇMB'ye ve IOWA Üniversitesi Öğretim Üyesi Prof. Dr. Halil Ceylan’a teşekkür ederiz.

\section{Kaynaklar}

[1] Güngör G., Sağlık A., Ünal N., Karayolu Beton Yol Deneme Kesimleri Performans Değerlendirmesi, Hazır Beton Kongresi, İstanbul-Türkiye, 1, 96-111, 2013.

[2] Yeğinboğa A., Türkiye'nin İlk Beton Karayolları, TÇMB / AR-GE Enstitüsü, Ankara, Türkiye, 2010.

[3] Hall K., Dawood D., Vanikar S., Tally R., Cackler T., Correa A., vd., Long-life Concrete Pavements in Europe and Canada, FHWA, ABD, 2007.

[4] Ağar E., Sütaş İ., Öztaş G., Beton Yollar, İstanbul Teknik Üniversitesi Yayınları, İstanbul, Türkiye, 1998.

[5] NCHRP Project 1-37A Report, Mechanistic-Empirical Design of New and Rehabilitated Pavement Structures, FHWA, ABD, 2004.

[6] Huang Y. H., Pavement Analysis and Design, 2.cilt,Par entice Hall, ABD, 2008.

[7] Ozturk H. I., Tan E. B., Sengun E., Yaman I. O., Comparison of jointed plain concrete pavement systems designed by mechanistic-empirical (M-E) method for different traffic, subgrade, material and climatic conditions, Journal of the Faculty of Engineering and Architecture of Gazi University, 2018.

[8] Sachs S., Vandenbossche J.M., Snyder M.B., Calibration of national rigid pavement performance models for the pavement mechanistic-empirical design guide, Transportation Research Record: Journal of Transportation Research Board, 2524 (6), 59-67, 2015.

[9] Mu F., Mack J.W., Rodden R.A., Review of national and state-level calibrations of AASHTOWare Pavement ME design for new jointed plain concrete pavement. Int $\mathbf{J}$ Pavement Eng, 19 (9), 825-831, 2018. 
[10] Kim S., Ceylan H., Ma D., Gopalakrishnan K., Calibration of pavement ME design and mechanistic-empirical pavement design guide performance prediction models for Iowa pavement systems, J Transp Eng, 140 (10), 2014.

[11] Vandenbossche J.M., Mu F., Burnham T.R., Comparison of measured vs. predicted performance of jointed plain concrete pavements using the Mechanistic-Empirical Pavement Design Guideline. Int J Pavement Eng, 12 (3), 239-251, 2011.

[12] Johanneck L., Tompkins D., Clyne T., Khazanovich L., Minnesota Road Research Data for Evaluation and Local Calibration of the Mechanistic-Empirical Pavement Design Guide's Enhanced Integrated Climatic Model, Transportation Research Record: Journal of Transportation Research Board, 2226 (4), 30-40, 2011.

[13] Li J., Uhlmeyer J., Mahoney J., Muench S., Updating the Pavement Design Catalog for the Washington State Department of Transportation: Using 1993 AASHTO Guide, Mechanistic-Empirical Pavement Design Guide, and Historical Performance, Transportation Research Record: Journal of Transportation Research Board, 2154 (12), 124-129, 2010.

[14] Bustos M., Cordo O., Girardi P., Pereyra M., Calibration of Distress Models from the Mechanistic-Empirical Pavement Design Guide for Rigid Pavement Design in Argentina, Transportation Research Record: Journal of Transportation Research Board, $2226(1), 3-12,2011$.

[15] Sadek H.A., Masad E.A., Sirin O., Al-Khalid H., Sadeq M.A., Little D., Implementation of mechanistic-empirical pavement analysis in the State of Qatar, Int $\mathbf{J}$ Pavement Eng, 15 (6), 495-511, 2014.

[16] Romero M.J.M.E., Garro N.M.T., Zevallos G.G., Implementation of the mechanisticempirical pavement design in northern Peru using a calibration coefficient for the International Roughness Index, Constr Build Mater, 102 (1), 270-280, 2016.

[17] El-Shaib M.A., El-Badawy S.M., Shawaly E.-S.A., Comparison of AASHTO 1993 and MEPDG considering the Egyptian climatic conditions, Innovative Infrastructure Solutions, 2 (18), 2017.

[18] Ameri M., Khavandi A., Development of mechanistic-empirical flexible pavement design in Iran, J Appl Sci, 9 (2), 354-359, 2009.

[19] Ghosh A., Padmarekha A., Krishnan J.M., Implementation and proof-checking of mechanistic-empirical pavement design for Indian highways using AASHTOWARE pavement ME design software, Procedia-Social Behav Sci, 104 (2), 119-128, 2013.

[20] Ma H., Wang D., Zhou C., Feng D., Calibration on MEPDG low temperature cracking model and recommendation on asphalt pavement structures in seasonal frozen region of China, Adv Mater Sci Eng, 2015.

[21] Delgadillo R., Wahr C., Alarcón J., Toward implementation of the mechanisticempirical pavement design guide in Latin America: Preliminary work in Chile, Transportation Research Record: Journal of Transportation Research Board, 2226 (16), 142-148, 2011. 
[22] Chehab G.R., Chehade R.H., Houssami L., Mrad R., Implementation Initiatives of the Mechanistic-Empirical Pavement Design Guide in Countries with Insufficient Design Input Data-The Case of Lebanon. Int. Congr. Exhib. Sustain. Civ. Infrastructures Innovative Infrastructure Geotechnology, Springer, 2017.

[23] Khattab A.M., El-Badawy S.M., Elmwafi M., Evaluation of Witczak E* predictive models for the implementation of AASHTOWare-Pavement ME Design in the Kingdom of Saudi Arabia, Constr Build Mater, 64, 360-369, 2014.

[24] Seo Y., Distress Evolution in Highway Flexible Pavements: A 5-Year Study at the Korea Highway Corporation Test Road, Journal of Test Evaluation, 38, 32-41, 2009.

[25] Ciro C., Local Calibration and Implementation of the Mechanistic-Empirical Pavement Design Guide for Flexible Pavement Design, J Transp Eng, 138 (3), 348-360, 2012.

[26] Rens L., Road Structures in Belgium and Specifications for Hydraulically Bound Mixtures for Base Layers, Brussels, Belgium, 2016.

[27] Kırbaş U., Karaşahin M, Şehiriçi Yollarda Üstyapıların Mevcut Performansını Belirlemek İçin Bir Yöntem, Teknik Dergi, 29, 8459-8467, 2018.

[28] Múčka P., International Roughness Index Specifications Around the World, Road Materials Pavement Design, 18, 929-965, 2017.

[29] Kırbaş U., Konforlu Sürüş için Uluslararası Düzgünsüzlük İndeksi Sınır Değerlerinin Belirlenmesi, Journal of Engineering Science, 6 (2), 301-309, 2018.

[30] ASTM E 950/E950M, Standard Test Method for Measuring the Longitudinal Profile of Traveled Surfaces with an Accelerometer-Established Inertial Profiling Reference, ASTM International, West Conshohocken, 2018.

[31] Merritt D. K., Chang G. K., Rutledge J. L., Best Practices for Achieving and Measuring Pavement Smoothness, A Synthesis of State-Of-Practice, FHWA/LA. 14/550, Louisiana Transportation Research Center, 2015.

[32] ACPA, Guide Specification- Smoothness Pavement Smoothness Requirements, American Concrete Pavement Association, 2013.

[33] KGM, Beton Yollar Teknik Şartnamesi, Karayolları Genel Müdürlüğü ARGE Daire Başkanlığg1, Ankara, Türkiye, 2016.

[34] ASTM E 274/E274M, Standard Test Method for Skid Resistance of Paved Surfaces Using a Full-Scale Tire, ASTM International, West Conshohocken, 2015.

[35] Hergüner A. T., Ağar E., Türkiye Otoyol Ağı için Üstyapı Performans Tahmin Modellerinin Geliştirilmesi, İTÜ Dergisi, 9, 2011.

[36] Hergüner A. T., Türkiye Otoyol Ağı İçin Üstyapı Yönetim Sistemi, Doktora Tezi, İstanbul Teknik Üniversitesi Fen Bilimleri Enstitüsü, 2009.

[37] TS EN 13036-1, Karayolunun ve Havaalanı Pistinin Yüzey Karakteristikleri - Deney Yöntemleri - Bölüm 1: Kaplama Yüzeyi Makro Doku Derinliğinin Hacimsel Alan Tekniği Kullanılarak Ölçülmesi, Türk Standartları Enstitüsü, Ankara, 2015. 
[38] Kaçmaz B., Topal A., Şengöz B., Tanyel S., Farklı Tip Esnek Kaplamaların Yol Yüzey Özelliklerinin Arazi Ölçümleriyle Değerlendirilmesi, Teknik Dergi, 26, 7115-7137, 2015.

[39] ACPA (American Concrete Pavement Association), Agency Practices Explorer. http://1734298.sites.myregisteredsite.com/legacyapps/APD.aspx. Erişim tarihi Temmuz 27, 2018.

[40] Karayolları Genel Müdürlüğü, Trafik Hacim Haritaları. http://www.kgm.gov.tr/Sayfalar/KGM/SiteTr/Trafik/TrafikHacimHaritasi.aspx. Erişim tarihi Ağustos 7, 2018.

[41] FHWA-HRT-13-091, Verification, Refinement, and Applicability of Long-Term Pavement Performance Vehicle Classification Rules, Georgetown Pike McLean, VA, ABD, 2014.

[42] American Association of State Highway and Transportation Officials (AASHTO), Mechanistic-Empirical Pavement Design Guide: A Manual of Practice, A.B.D., 2008.

[43] American Association of State Highway and Transportation Officials (AASHTO), Guide for Design of Pavement Structures, vol. 1, 1993.

[44] Elshaeb M.A., El-Badawy S.M., Shawaly E-S.A., Development and Impact of the Egyptian Climatic Conditions on Flexible Pavement Performance, American Journal of Civil Engineering and Architecture, 2 (3), 115-121, 2014.

[45] KGM, Karayolları Esnek Üstyapılar Projelendirme Rehberi, Karayolları Genel Müdürlüğü Teknik Araştırma Dairesi Başkanlığı, Ankara, Türkiye, 2008.

[46] Haas R., Hudson W. R., Zaniewski J. P., Modern Pavement Management, Krieger Publishing Company Malabar, FL, 1994.

[47] Shahin M. Y., Pavement Management for Airports, Roads, and Parking Lots, Springer New York, 2005.

[48] Kırbaş U., Karaşahin M., Performance Models for Hot Mix Asphalt Pavements in Urban Roads, Construction Building Materials, 116, 281-288, 2016. 